\title{
Performance Based Incentives Policy: A Geometric Hybrid Model
}

\author{
Ch. Hari Govinda Rao ${ }^{1}$, Pavan Krishna Kosaraju ${ }^{1}$ and Hye-jin Kim ${ }^{2 *}$ \\ ${ }^{1}$ Department of MBA, Vignan's Institute of Information Technology, \\ Visakhapatnam-530049, India \\ ${ }^{2}$ Sungshin Women's University, Bomun-ro 34da-gil, \\ Seongbuk-gu, Seoul, Korea \\ \{harigovindarao,pavan.krishna\}@gmail.com,*hyejinaa@daum.net
}

\begin{abstract}
Performance based incentives are incentives that are disbursed based on the authentic performance of an employee for a stipulated resulted period. Using a PBI policy is enormously successful in inspiring professors and other stakeholder to focus on core areas of an educational institute. In this article, the author proposed a geometric hybrid model for computing performance based an incentive which helps to tie compensation directly to specific institutional goals and management objectives of an institute. In PBI policy, performance of the faculty is always evaluated based on his or her academic output in terms of result or percentage of marks. However sometimes faculty argues that academic output always depends on the subject toughness rather than the faculty's performance in terms of results. On the contrary, someone may be argued that the criteria of student feedback system are the best decisive factor to evaluate faculty's performance. Hence, a traditional PBI policy always consider both the results and student feedback criterion as decisive factor for appraising faculty's performance but it was failed in considering subject toughness and quality of students input. To overcome this gap, the author proposed a geometric hybrid model of performance based incentive policy which considers a set of notional variable like, subject toughness, subject's results and average result of all subjects. This geometric hybrid model delivers competitive pay for cutthroat levels of performance and also encourages employees to constantly develop new skills. This model suggests a mathematical proposition for evaluation of professor's performance through justification proportionate variables in technical educational institutes.
\end{abstract}

Keywords: PBI Policy, Geometric hybrid model, Measurement \& Result analysis

\section{Introduction}

Incentives are instant rewards and they create immediate effect on performance. Some of the researchers portrayed that faculty is always rewarded based on his/her output. Since the quality of output rewarded, most of the eminent faculty can be moved to areas of low socio-economic status due to lack of a fast track mechanism to identify the performance and propose the incentives. Hence, a strong performance appraisal system assists an educational institute to establish potential man force; analysis employee performance is essential to determine if further training is needed or if dismissal is appropriate. Sanction of the incentive is always preceded by appraisal of an employee at various levels. At the same time, it's also required to consider special incentives for specific individual performances which should be made with orderly paid, in order that the employee gets motivated by the appreciation of his/her contribution and uphold self-esteem. As per the psychometric studies motivation plays a vital role in law of behavior that higher

${ }^{*}$ Corresponding Author 
impetuses will prompt to predominant execution. Hence, a performance based incentive methodology always helps to tie compensation straight to specific organizational goals and management objectives $[9,11,16]$.

\section{Performance Incentive Policy}

In conventional policy, some unwanted issues like, politics, religion, caste, greed, and friendship administration's binding etc., have taken an edge to reward some ineffective people and correspondingly it neglects talented man force. Later, Faculty compensation has long been based solely considered on "personality development" criterion such as "length of service and level of education attained" to aim at preventing pay inequity between men and women staff. Recently, this conventional compensation procedure has been commented as there are weak relationships among faculty skills, faculty development, student performance, and faculty recognition. PBI policy for faculty would only strengthen the good old boy network in an educational institution. PBI delivers competitive pay for competitive levels of performance and also encourages employees to constantly develop new skills. Even some of the researchers argued that most of the conventional systems of performance based incentive system had a problem with encouraging co-operation $[2,15]$. In this manner, a considerable collection of writing contends performance-based reward systems are a change on the proficiency of pay scales [13].

\section{Literature Review}

In olden days, teachers have been paid with fixed salary and wages schedules, with determined solely by educational attainment and years of experience. Afterward, the concept of performance based incentive has been receiving increasing attention over the recent decade in the literature. In olden days, majority of the programmes focused on individual performance in a particular merit pay [17], but in recent trends more likely to consider intellectual criterion like, knowledge and skill based rewards [2,14]. The theory following performance pay holds with the intention of making pay in division contingent on performance provides best incentives to improve outcomes of interest [19]. Administrative condense study has shown that teachers are the most significant factors related to student learning and achievements [3]. In more extensive sense, execution pay framework arrangements are urged as substitute to the single compensation plan with the objective of drawing in and holding proficient people from different fields of career. Compensation system is one of the major components of any strategic management system, which can be intended to strengthen the strategic goals of the institution [1]. Class room observations are the more often used assessment systems for teachers [4]. A good amount of literature has examined about the unbending structure of teacher compensation policies and their role in encouraging student career $[6,8,10]$. Majority of the teacher's appraisal systems rewarded for the teachers experience and their credentials rather than their performance [15]. Though the year of experience and advanced degrees are the determinant factors of teacher's pay, they are not closely correlated to student performance or institutional outcomes [5,18].

Hoerr portrayed that any non-merit-based system is injustice for outstanding faculty for the reason that they are not judged on efficient criteria [7]. Whilst performance is recognized, teachers' salaries sometimes equal to the private sector without having any growth in pay scale [21]. Performance base rewards are the distinct feature performance based incentive policy [2]. Hence, "pay-for-performance" is a popular education reform, but there is little evidence about the characteristics of a well-designed incentive pay plan for teachers [12]. 


\section{Statement of the Problem}

PBI schemes in India are comparatively young when compared to world's history and most of the studies addresses the importance of PBI policy, challenges, nuances, specific development strategies in PBI policy. There are many studies which have given an attention to the concept and its application process at school level teachers. In spite of the massive amount of literature, there is no particular review which brings critical numerical model of utilization at institute level. Particularly in the field of technical education in India, there is no focus on the study of mathematical model of PBI. There is likewise a need to think about the issues of PBI policy in India with a special focus on technical institutions like engineering colleges where performance appraisal is concentrated. In the above context, the present study reviews the evaluation of PBI Policy and undertakes a study which divulges a mathematical proposition for assessment of performance appraisal in engineering colleges. The side effects uncovered by the examination of the PBI arrangement would give helpful knowledge to the strategy creators, staff and different partners of the establishment. The review would highlight the areas that need to evaluate and hone the comprehension of the connections between key elements for appraisal of staff.

\section{Hybrid Model Performance Based Incentive (GHMPBI) Policy}

Educators in many parts of the world are remunerated in view of degrees and experience. In any case, a considerable lot of the analysts came about that the rewards to experience are constrained and that qualifications have minor effect on understudies' execution. By and by, educators' quality is vital. As a result of this distinction between educator remuneration and instructor execution, the possibility of budgetary motivating forces for instructors (regularly called as Performance Based Incentive or Merit Based Incentive) related with occasions of understudy execution has turned out to be increasingly acknowledged and well known. In this way, a generous assemblage of literature argued that the performance based incentive frameworks with the mix of all parameters incorporate in establishing objectives are a change on the productivity of pay scales. Pioneering incentive mechanisms based on loss rather than gain or on relative student performance show promise for high effectiveness but are yet to be rigorously evaluated [20]. With this motivation this paper presented a hybrid model with combination of all parameters of faculty assessment.

\subsection{Influence behind GHMPBI Policy}

Traditional PBI policy determined objectively where as GHMPBI policy provides fair and accurate evaluation both objectively and subjectively. It creates competition among professors in terms of their results, research output correspondingly which uplifts the institute goals. In this GHMPBI policy, higher performer always encourages with higher incentive. A range of perverse outcomes occur because of faculty 'game playing' to impress the superior rather than his or her core values. Whereas in case of GHMPBI policy fully automated which creates better opportunities to prove individual by creating competition among them. GHMPBI policy can be implemented easily by adopting a simple data base system with the help of simple software. The details of the model are presented in the Table1 below. 


\section{Table 1. Model of Geometric Hybrid Model Performance Based Incentive} Policy

\begin{tabular}{|c|c|c|c|c|}
\hline Criteria & $\begin{array}{l}\text { Academic } \\
\text { results }\end{array}$ & $\begin{array}{c}\text { Student } \\
\text { Feedback }\end{array}$ & $\begin{array}{c}\text { Research \& } \\
\text { Development }\end{array}$ & $\begin{array}{c}\text { Other } \\
\text { Contribution }\end{array}$ \\
\hline $\begin{array}{l}\text { Maximum } \\
\text { Credits } \\
\text { Awarded }\end{array}$ & 3 & 1 & 3 & 3 \\
\hline $\begin{array}{c}\text { Scope of } \\
\text { compensation }\end{array}$ & $\begin{array}{l}\text { All faculty who } \\
\text { can achieve } \\
\text { maximum } \\
\text { academic } \\
\text { Results }\end{array}$ & $\begin{array}{l}\text { All faculty who } \\
\text { can achieve } \\
\text { maximum } \\
\text { student } \\
\text { feedback score }\end{array}$ & $\begin{array}{l}\text { All faculty } \\
\text { who can } \\
\text { progress } \\
\text { through their } \\
\text { research }\end{array}$ & $\begin{array}{l}\text { All professors } \\
\text { who can support } \\
\text { the students, } \\
\text { peers, and } \\
\text { institute }\end{array}$ \\
\hline $\begin{array}{c}\text { Areas } \\
\text { evaluated }\end{array}$ & $\begin{array}{l}\text { Evaluated on } \\
\text { the premise of } \\
\text { showed abilities } \\
\text { and information } \\
\text { which are } \\
\text { thought to be } \\
\text { connected to } \\
\text { expanded staff } \\
\text { performance. } \\
\text { Regularly } \\
\text { comes as } \\
\text { Academic } \\
\text { outcomes }\end{array}$ & $\begin{array}{l}\text { Assessed on the } \\
\text { premise of } \\
\text { exhibited } \\
\text { aptitudes and } \\
\text { learning which } \\
\text { are thought to } \\
\text { be connected to } \\
\text { expanded staff } \\
\text { performance. } \\
\text { Regularly } \\
\text { comes as } \\
\text { Students input }\end{array}$ & $\begin{array}{l}\text { Assessed on } \\
\text { the basic of } \\
\text { output } \\
\text { connected to } \\
\text { faculty } \\
\text { research area. } \\
\text { Often comes } \\
\text { as quality } \\
\text { distributions }\end{array}$ & $\begin{array}{l}\text { Evaluated on the } \\
\text { premise of } \\
\text { workforce yield } \\
\text { as additional } \\
\text { commitments for } \\
\text { advancement of } \\
\text { understudy, self } \\
\text { and } \\
\text { establishment. } \\
\text { Like, student } \\
\text { counseling, } \\
\text { discipline and } \\
\text { Peers feedback } \\
\text { often } \\
\text { comes in the } \\
\text { form of } \\
\text { other credentials }\end{array}$ \\
\hline
\end{tabular}

\subsection{Hypothesis \& Methodology}

Keeping in view the importance of the study and in light of the above parameters, this study attempts a geometric model of experiments to test the performance appraisal. The main aim of this model is to develop a comprehensive mathematical model which would be suitable to technical institutions to assess an annual academic appraisal of a faculty. The propositions of this model are:

1. The growth \& development of any technical institute may depends on its overall students results, students feedback on faculty teaching methodology, its research output of institute and other contributions. Hence, the author presumed that there are four basic parameters may influence the institute development and growth like, Student academic results, feedback, Faculty development through research \& development. Subject wise toughness plays a vital role in producing good results. Since student result being played a vital role PBI policy, some of the faculty expressed their un-happiness and it is also pointed out that the student result is fortunately depends on students' intelligence and paper toughness. For this reason, qualitative staff may get disappointed. Therefore, this study considers comparative result score within the same section and results of the other sections.

2. The quality of students may differ from section to section. Hence, the author also assumed that number of sections also plays an important role in a technical institute which comprises with many sections and different faculty may teach the same 
subject for different sections. In light of the above recommendations, the review endeavors to test the accompanying speculations:

$\mathrm{H}_{1}$ : It is hypothesized that there is a strong significant association between the result range within the same section and the result of the same subject in other section.

H0: It is estimated that there is no relationship between individual subject result and other subject's results.

Based on the above hypothesis, the GHMPBI proposes TEN point scales to evaluate a professors' performance in a technical institute. Mainly the GHMPBI Policy considers all the core areas of a technical institutional objectives like, Academic Result (AR), Academic Feedback (AF), Research \& Development (RD) and other contributions (OC) of an employee for his/her improvement as well as institutional growth. The details of the weighted score for the above criteria are given below:

$\begin{array}{ll}\text { Weighted Academic Result Score (WARS) } & =3 \text { Marks } \\ \text { Weighted Academic Feedback Score (WAFS) } & =1 \text { Marks } \\ \text { Weighted Research \& Development Score (WRDS) } & =3 \text { Marks } \\ \text { Weighted other contributions Score (Wocs) } & =3 \text { Marks } \\ \text { Mathematically it can be expressed as: } & \end{array}$

Mathematically it can be expressed as:

PBI score of an Employee $=\left[\left(\sum\right.\right.$ ARS. WARS $)+\left(\sum\right.$ AFS. WAFS $)+\left(\sum\right.$ RDS.WRDS $)+$ ( OCS. Wocs)] (1)

ARS = Academic Result Score;

AFS=Academic Feedback Score;

RDS = Research \& Development Score;

OCS $=$ other contributions Score

3. Assessment of "Academic Result Score (ARS)": This criterion mainly focuses on the academic performance of an employee which covers the semester results of an employee in an academic year. The author proposes 3 marks in this criterion based on the following propositions:

$>$ It considers Individual Subject Result Analysis within the class/section when compared to other subjects of the same class.

$>$ It also considers the performance of individual subject result when compared to the result of the same subject in all sections of all the branches. Based upon above propositions, the author develops the following Geometric Hybrid Model for computation of Academic Performance Score (APS):

$$
\sum \text { ARS.WAP }=\left[\frac{A R S_{1}+A R S_{2}+\ldots \ldots \ldots \ldots+A R S_{n}}{n}\right]
$$

Alternatively:

$$
\begin{gathered}
\sum \text { APS.WAP }=\frac{\sum_{i=1}^{n} A R S_{i}}{n} \\
=\frac{\left[\left[1-(x-y)^{2} \times 10\right] \times 3\right]+\left[\left[1-(z-y)^{2} \times 10\right] \times 3\right]}{2}
\end{gathered}
$$

$\sum$ APS. $\mathrm{W}_{\mathrm{AP}}=$ Weighted average score of academic results performance

$A R S_{1}=$ Academic Result Score of a subject

$x=$ Highest percentage of the subject result within the section

$y=$ Percentage of the concerned subject of the individual faculty

$z$ = Highest Percentage of the same subject result in the entire college within the semester

$n=$ total number of papers taught by the individual faculty in stipulated period 


\subsubsection{Result Analysis \& Interpretation}

Case 1: Employee No: 10432 taught CNS subject for IT-IV-1and secured 95.12\% result. The same subject (CNS) result of the other sections also resented the Table 2.

Table 2. Result of the CNS Subject and Other Subjects of the Same Section

\begin{tabular}{|c|r|c|c|}
\hline Branch & Subjects & Empl. Id & Result (Pass \%) \\
\hline \multirow{3}{*}{ IT - } & $y_{1=}$ CNS & $\mathbf{1 0 4 3 2}$ & $\mathbf{9 5 . 1 2 \%}$ \\
\cline { 2 - 4 } IV-1 & OSS & 10093 & $90.24 \%$ \\
\cline { 2 - 4 } & $x_{\mathbf{1}=\mathbf{M C}}$ & $\mathbf{1 0 0 8 8}$ & $\mathbf{1 0 0 \%}$ \\
\cline { 2 - 4 } & DP & 10647 & $98 \%$ \\
\cline { 2 - 4 } & IRS & 10646 & $97 \%$ \\
\cline { 2 - 4 } & DWDM & 10094 & $90.24 \%$ \\
\hline
\end{tabular}

Table 3. CNS Subject Result of Various Sections in the Same Semester

\begin{tabular}{|l|r|c|c|}
\hline Branch & Subject & Empl. ID & Result (Pass \%) \\
\hline \multirow{4}{*}{ IV CSE - } & SPM & 10441 & 100 \\
\cline { 2 - 4 } & $z_{\mathbf{1}=\mathbf{C N S}}$ & $\mathbf{1 0 5 2 6}$ & $\mathbf{1 0 0}$ \\
\cline { 2 - 4 } & UMLDP & 10540 & 100 \\
\cline { 2 - 4 } & MC & 10552 & 100 \\
\cline { 2 - 4 } & DMDW & 10572 & 100 \\
\hline \multirow{4}{*}{ IV CSE - } & OSS & 10009 & 100 \\
\cline { 2 - 4 } & SPM & 10420 & 100 \\
\cline { 2 - 4 } & CNS & $\mathbf{1 0 0 6 2}$ & $\mathbf{8 4}$ \\
\cline { 2 - 4 } & UMDP & 10539 & 98 \\
\cline { 2 - 4 } & MC & 10606 & 100 \\
\hline \multirow{5}{*}{ IV CSE - 3 } & OSS & 10467 & 100 \\
\cline { 2 - 4 } & SPM & 10441 & 89 \\
\cline { 2 - 4 } & CNS & $\mathbf{1 0 5 2 6}$ & 80 \\
\cline { 2 - 4 } & UMLDP & 10540 & $\mathbf{5 2}$ \\
\cline { 2 - 4 } & DMDW & 10552 & 81 \\
\hline \multirow{5}{*}{} & OSS & 10572 & 77 \\
\hline
\end{tabular}

$x_{1}=100 \%$ ( Subject MC Result); $y_{1}=95.12 \%$ (Subject CNS Result); $z_{1}=100 \%($ Subject CNS in section IV CSE -1 Result $=100 \%)$; $\mathrm{i}=$ subject number taught by a faculty; i.e. 1

$$
\begin{gathered}
A R S_{1}=\frac{\left[\left[1-(x-y)^{2} \times 10\right] \times 3\right]+\left[\left[1-(z-y)^{2} \times 10\right] \times 3\right]}{2} \\
A R S_{1}=\frac{\left[\left[1-(100 \%-95.12 \%)^{2} \times 10\right] \times 3\right]+\left[\left[1-(100 \%-95.12)^{2} \times 10\right] \times 3\right]}{2} \\
A R S_{1}=\frac{2.928+2.928}{2}
\end{gathered}
$$

If professor taught only one subject in an year his or her Academic results score $\left(\sum\right.$ APS. $\left.\mathrm{W}_{\mathrm{AP}}\right)$ is 


$$
\sum \text { APS. } \mathrm{W}_{\mathrm{AP}}=\frac{\sum_{i=1}^{n}[2.928]}{n}=\frac{2.928}{1}=2.928
$$

Case 2: If the same Employee No: 10432 is also having OSS subject for IV CSE - 2 and he has secured $57 \%$ result. It is very low \% when compared to other subjects result. The detailed result analysis the same section and other section given below:

Table 4. Result of the CNS Subject and Other Subjects of the Same Section

\begin{tabular}{|c|r|c|c|}
\hline Branch & Subjects & Empl. Id & Result (Pass \%) \\
\hline \multirow{4}{*}{ IV CSE -2} & SPM & 10441 & 60 \\
\cline { 2 - 4 } & CNS & 10526 & 52 \\
\cline { 2 - 4 } & $\boldsymbol{x}_{2}=\mathbf{U M L D P}$ & $\mathbf{1 0 5 4 0}$ & $\mathbf{7 1}$ \\
\cline { 2 - 4 } & MC & 10552 & 64 \\
\cline { 2 - 4 } & DMDW & 10572 & 59 \\
\cline { 2 - 4 } & $y_{2=} \mathbf{O S S}$ & $\mathbf{1 0 4 3 2}$ & $\mathbf{5 7}$ \\
\hline
\end{tabular}

Table 5. OSS Subject Result of Various Sections in the Same Semester

\begin{tabular}{|c|r|c|c|}
\hline Branch & Subjects & Empl. Id & Result (Pass \%) \\
\hline \multirow{4}{*}{ IT Dept./ } & CNS & 10432 & $95.12 \%$ \\
\cline { 2 - 4 } IV-1 & OSS & 10093 & $80.24 \%$ \\
\cline { 2 - 4 } & MC & 10088 & $100 \%$ \\
\cline { 2 - 4 } & DP & 10647 & $100 \%$ \\
\cline { 2 - 4 } & IRS & 10646 & $100 \%$ \\
\hline \multirow{4}{*}{ IV CSE - 1 } & SPM & 10094 & $90.24 \%$ \\
\cline { 2 - 4 } & CNS & 10441 & 100 \\
\cline { 2 - 4 } & UMLDP & 10526 & 100 \\
\cline { 2 - 4 } & MC & 10540 & 100 \\
\cline { 2 - 4 } & DMDW & 10572 & 100 \\
\cline { 2 - 4 } & $z_{1=}$ OSS & $\mathbf{1 0 0 0 9}$ & 100 \\
\hline \multirow{4}{*}{ IV CSE - 3 } & SPM & 10420 & $\mathbf{8 1}$ \\
\cline { 2 - 4 } & CNS & 10062 & 100 \\
\cline { 2 - 4 } & UMLDP & 10539 & 94 \\
\cline { 2 - 4 } & MC & 10606 & 100 \\
\cline { 2 - 4 } & DMDW & 10467 & 100 \\
\cline { 2 - 4 } & OSS & 10072 & 79 \\
\hline
\end{tabular}

$x_{2}=71 \%\left(\right.$ Subject UMLDP result); $y_{2}==57 \%\left(\right.$ OSS result $; Z_{2}=81 \%($ Subject OSS

$$
\begin{gathered}
\sum \mathrm{APS}_{2}=\frac{\left[\left[1-(71 \%-57 \%)^{2} \times 10\right] \times 3\right]+\left[\left[1-(81 \%-57 \%)^{2} \times 10\right] \times 3\right]}{2} \\
\sum \mathrm{APS}_{2}=\left[\begin{array}{c}
\left.\frac{2.412+1.272}{2}\right] \\
\sum \mathrm{APS}_{2}=1.842
\end{array}\right]
\end{gathered}
$$

If professor taught TWO subjects in an year his or her Academic results score ( $\sum$ APS. $\mathrm{W}_{\mathrm{AP}}$ ) is 


$$
\begin{gathered}
\sum A P S . W_{A P}=\left[\frac{A R S_{1}+A R S_{2}}{2}\right] \\
\sum A P S . W_{A P}=\left[\frac{2.928+1.842}{2}\right] \\
\sum A P S . W_{A P}=2.385
\end{gathered}
$$

Case 3: Employee No: 11572 is having DWDM subject for IV CSE - 3 and secured $62 \%$ result. The same subject (DWDM) result of the other also given below.

Table 6. Result of the CNS Subject and Other Subjects of the Same Section

\begin{tabular}{|c|r|c|c|}
\hline Branch & \multicolumn{1}{|c|}{ Subjects } & Empl. Id & Result (Pass \%) \\
\hline \multirow{4}{*}{ IV CSE - 3 } & SPM & 10441 & 80 \\
\cline { 2 - 4 } & CNS & 10526 & 52 \\
\cline { 2 - 4 } & $\boldsymbol{x}_{2}=$ UMLDP & 10540 & 91 \\
\cline { 2 - 4 } & $y_{\mathbf{1}=\mathrm{DWDM}}$ & 10552 & 84 \\
\cline { 2 - 4 } & OSS & 10572 & 62 \\
\hline
\end{tabular}

Table 7. DWDM Subject Result of Various Sections in the Same Semester

\begin{tabular}{|c|r|c|c|}
\hline Branch & Subject & Empl. ID & Result (Pass \%) \\
\hline \multirow{4}{*}{$\begin{array}{c}\text { IT Dept./ } \\
\text { IV-1 }\end{array}$} & CNS & 10432 & $95.12 \%$ \\
\cline { 2 - 4 } & OSS & 10093 & $90.24 \%$ \\
\cline { 2 - 4 } & MC & 10088 & $100 \%$ \\
\cline { 2 - 4 } & DP & 10647 & $100 \%$ \\
\hline \multirow{5}{*}{ IV CSE - 1 } & IRS & 10646 & $100 \%$ \\
\cline { 2 - 4 } & DWDM & 10094 & $90.24 \%$ \\
\cline { 2 - 4 } & SPM & 10441 & 100 \\
\cline { 2 - 4 } & CNS & 10526 & 100 \\
\cline { 2 - 4 } & $z_{1}$ DWDP & 10540 & 100 \\
\hline \multirow{5}{*}{ IV CSE - 2} & MC & 10552 & 100 \\
\cline { 2 - 4 } & OSS & 10572 & 100 \\
\cline { 2 - 4 } & SPM & 10009 & 10420 \\
\cline { 2 - 4 } & CNS & 10062 & 100 \\
\cline { 2 - 4 } & UMLDP & 10539 & 98 \\
\cline { 2 - 4 } & MC & 10606 & 100 \\
\hline
\end{tabular}

$$
\begin{aligned}
& x=91 \% ; y=62 \% ; z=100 \% \\
& \underline{\left[\left[1-(91 \%-62 \%)^{2} \times 10\right] \times 3\right]+\left[\left[1-(100 \%-62 \%)^{2} \times 10\right] \times 3\right]} \\
& \sum \mathrm{APS}_{2}= \\
& 2 \\
& \sum \mathrm{APS}_{2}=\left[\frac{0.477+(-1.776)}{2}\right] \sum A P S_{2}=-0.6495
\end{aligned}
$$

Case 4: Employee No: 11573 is having SE subject for ECM and secured 68\% result. The same subject (SE) result of the other also given below. 
Table 8. Result of the CNS Subject and Other Subjects of the Same Section

\begin{tabular}{|c|r|c|c|}
\hline Branch & Subject & Empl. ID & Result (Pass \%) \\
\hline \multirow{4}{*}{ E.COM } & $y_{1=C G}$ & 11001 & $75 \%$ \\
\cline { 2 - 4 } & DAA & 11002 & $60 \%$ \\
\cline { 2 - 4 } & DICA & 11003 & $52 \%$ \\
\cline { 2 - 4 } & $\boldsymbol{x}_{2}=\mathrm{SE}$ & 11004 & $68 \%$ \\
\cline { 2 - 4 } & $\mathrm{MS}$ & 11005 & $70 \%$ \\
\cline { 2 - 4 } & LICA & 11006 & $50 \%$ \\
\hline
\end{tabular}

Table 9. CG Subject Result of Various Sections in the Same Semester

\begin{tabular}{|c|c|c|c|}
\hline Branch & Subject & Empl. ID & Result (Pass \%) \\
\hline \multirow{4}{*}{ IT } & ADS & 11007 & $65.12 \%$ \\
\cline { 2 - 4 } & SE & 11008 & $64.12 \%$ \\
\cline { 2 - 4 } & CN & 11009 & $72.68 \%$ \\
\cline { 2 - 4 } & OS & 11010 & $72.68 \%$ \\
\cline { 2 - 4 } & WT & 11012 & $57.56 \%$ \\
\cline { 2 - 4 } & $z_{1=}$ CG & 11013 & $76.00 \%$ \\
\hline
\end{tabular}

$$
\begin{gathered}
x=75 \% ; y=68 \% ; z=76 \% \\
\mathrm{APS}_{2}=\frac{\left[\left[1-(75 \%-68 \%)^{2} \times 10\right] \times 3\right]+\left[\left[1-(76 \%-68 \%)^{2} \times 10\right] \times 3\right]}{2} \\
\sum \mathrm{APS}_{2}=\left[\frac{2.853+2.808}{2}\right] \\
\sum \mathrm{APS}_{2}=2.8305
\end{gathered}
$$

\subsubsection{Case Analysis \& Interpretation}

Case - 1: In this case author attempted a stable result range between the results of same section and the result of the same subject when compared to other sections. That means the result range between CNS and other subjects of same section is 4.88\%. Empl. Id: 10432 is positioned at second best in-terms of subject result of the same section. However, he also got a positive result through PBI system when it considers CNS result of other sections in the same semester. Therefore, PBI resulted with a positive score and awarded "2.978" score for given Empl.ID 10432.

Case - 2: This paper also experimented with large result range in case 2. It is found that the result range between OSS and other subjects of same section is $14 \%$. At the same time, it ranged with $24 \%$ when compared to other sections. Empl. Id. 11432 is positioned at last before in-terms of subject result of the same section. However, he got a positive result through PBI system when it considers OSS result of other sections in the same semester. Therefore, PBI resulted a positive score and awarded with "1.842".

Case-3: Empl. Id: 11572 had positioned at fourth among six subjects in-terms of subject result of the same section. However, he also got a negative result through PBI system when it considers DWDM result of other sections in the same semester. At this juncture, it can be noticed that the result range between DWDM and other subjects of same section is $29 \%$. At the same time, it ranged with $33 \%$ when it compared to other 
sections. Therefore, PBI resulted with a negative score and awarded "- 0.6495 " score and awarded with 0 score of PBI for given Empl.ID 11572.

Case-4: In this example, employee is having SE subject for ECM branch which is single section and at the same time, there is one competitive section for that i.e. IT is also single section. He positioned at third best among six subjects in-terms of subject result of the same section. However, he also got a positive result through PBI system when it considers SE result of other section in the same semester. At this juncture, it can be noticed that the result range between SE and other subjects of same section is 7\%. At the same time, it ranged with $8 \%$ when it compared to other sections. Therefore, PBI resulted with a positive score and awarded " 2.8305 " score for given employee.

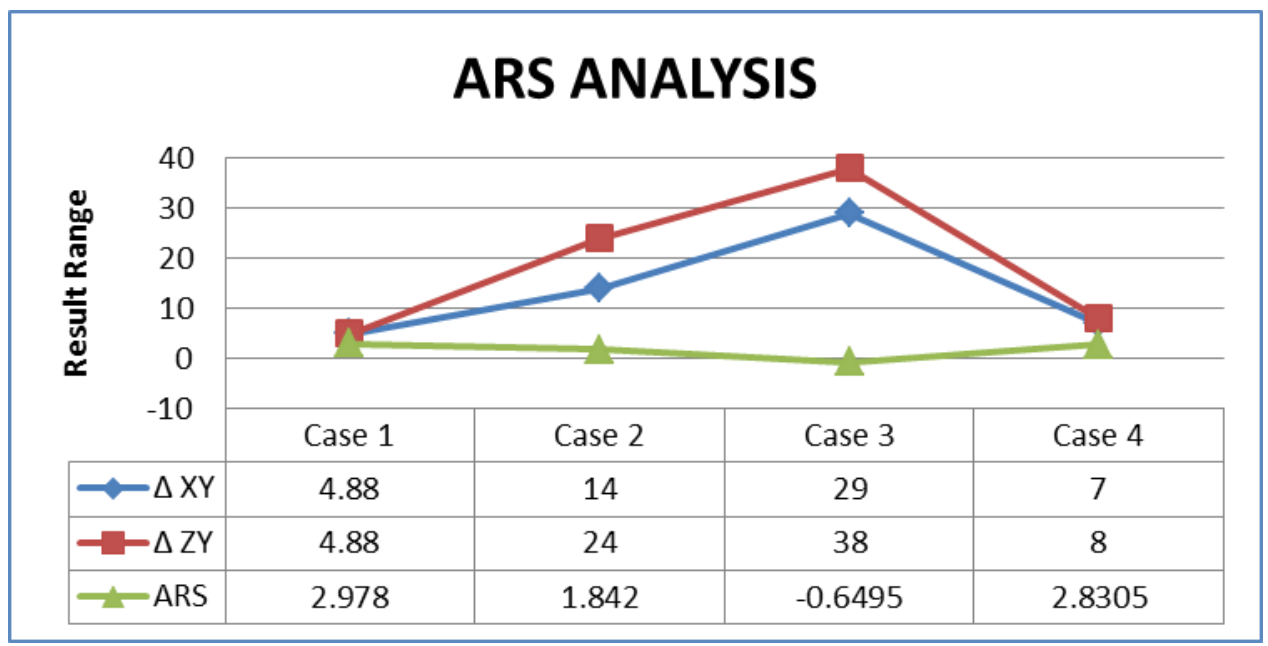

Figure 1. Graphical Representation of ARS Analysis

1. If an employee secured $x-y<30$ and $z-x<30$ his/her PBI is always positive result

2. If an employee secured $x-y>30$ and $z-x<30$ his/her PBI is also positive result

3. If an employee secured $x-y>30$ and $z-x>30$ his/her PBI is negative result

From the graphical representation Figure 1, it can be understood that the tendency of "academic result score" in different cases. The study identified a constant result of ARS with same result range between same section and other sections [case 1], At the same it also produces a low result of ARS where the result range $\Delta$ zy is more than $\Delta x y$. It indicates that the top performer of the same section may not obtain good score if the range is high when compared to other sections [case 2, case 3]. The analysis also showed the impact of result range in [case 4]. At the outset, the faculties who have produced good result he/she will get good score even in the subject toughness situation. Therefore, the employees must secure a positive score of ARS to acquire good PBI score. Subsequently, he/she would be eligible for BETTER increments.

\subsection{Assessment of Academic Feedback Score (AFS)}

This is the second criterion of the GHMPBI policy which proposed the following to assess the student's feedback. There are nine question put forward to students, for that they will allot 0-10 marks for individual questions on individual subject. Finally, the study considers average score of subject feedback for individual subjects and consolidates total subjects feedback score. 
Table 10. The Details of the Questions and their Mathematical Equation

\begin{tabular}{|c|l|c|c|c|c|}
\hline Criterion & Question & $\mathbf{S 1}$ & $\mathbf{S 2}$ & $\mathbf{S 3}$ & $\mathbf{S 4}$ \\
\hline Q1 & $\begin{array}{l}\text { Clarity in Presentation of Topics in the class \& } \\
\text { Subject knowledge of the faculty }\end{array}$ & $\mathrm{SQ}_{11}$ & $\mathrm{SQ}_{12}$ & $\mathrm{SQ}_{13}$ & $\mathrm{SQ}_{14}$ \\
\hline Q2 & Courteous and impartial to students & $\mathrm{SQ}_{21}$ & $\mathrm{SQ}_{22}$ & $\mathrm{SQ}_{23}$ & $\mathrm{SQ}_{24}$ \\
\hline Q3 & Coverage of the syllabus as per lecture plan & $\mathrm{SQ}_{31}$ & $\mathrm{SQ}_{32}$ & $\mathrm{SQ}_{33}$ & $\mathrm{SQ}_{34}$ \\
\hline Q4 & Discipline maintenance in the class & $\mathrm{SQ}_{41}$ & $\mathrm{SQ}_{42}$ & $\mathrm{SQ}_{43}$ & $\mathrm{SQ}_{44}$ \\
\hline Q5 & Doubt clearance & $\mathrm{SQ}_{51}$ & $\mathrm{SQ}_{52}$ & $\mathrm{SQ}_{53}$ & $\mathrm{SQ}_{54}$ \\
\hline Q6 & Faculty comes to class on time & $\mathrm{SQ}_{61}$ & $\mathrm{SQ}_{62}$ & $\mathrm{SQ}_{63}$ & $\mathrm{SQ}_{64}$ \\
\hline Q7 & Faculty speaks clearly and audibility & $\mathrm{SQ}_{71}$ & $\mathrm{SQ}_{72}$ & $\mathrm{SQ}_{73}$ & $\mathrm{SQ}_{74}$ \\
\hline Q8 & Faculty writes and draw legibly & $\mathrm{SQ}_{81}$ & $\mathrm{SQ}_{82}$ & $\mathrm{SQ}_{83}$ & $\mathrm{SQ}_{84}$ \\
\hline Q9 & Motivates the students to study & $\mathrm{SQ}_{91}$ & $\mathrm{SQ}_{92}$ & $\mathrm{SQ}_{93}$ & $\mathrm{SQ}_{94}$ \\
\hline & & $\mathrm{AFS}_{1}$ & $\mathbf{A F S}_{2}$ & $\mathbf{A F S}_{3}$ & $\mathbf{A F S}_{4}$ \\
\hline
\end{tabular}

$$
\begin{gathered}
\mathrm{AFS}=\frac{\sum_{i=1}^{n} \overline{A F S_{i}}}{n} \\
A F S_{1}=\sum_{i=1}^{9} S Q_{i 1}
\end{gathered}
$$

Here,

$A F S_{1}=$ Average score of a subject feedback

$S Q_{i 1}=A$ criterion for students' feedback

$n=$ number of subjects taught by a professor in an academic year

\subsection{Assessment of Research \& Development Score (RDS)}

The THIRD criterion of PBI is an Academic Research \& Development and its main features are as given below:

a. This criterion mainly considers the faculty output in Research and development in an academic year

b. Here R\&D includes Research article produced in the National and International Journals, Articles presented in the national and International Conferences, Conferences/ Workshops/ Symposium organized and participated.

c. It also consider the quality of research and ARDS score computed based on Global $\mathrm{R} \& \mathrm{D}$ quality indexes like, Citation, impact factor and $\mathrm{H}$-index etc.

Statement of Evaluation Score of ARDS is shown as below. 
Table 11. Statement of Evaluation Score of ARDS

\begin{tabular}{|c|c|c|c|c|c|}
\hline Category(c) & Paper with+(p) & $\begin{array}{l}\text { Index/Citation } \\
\text { value (i) }\end{array}$ & $\begin{array}{l}\text { Weight } \\
\left(\mathbf{W}_{\text {pci }}\right)\end{array}$ & $\begin{array}{r}\text { Marks } \\
\left(\mathbf{M}_{\mathrm{pci}}\right)\end{array}$ & $\begin{array}{c}\text { Total } \\
\text { weighted } \\
\text { score } \\
\text { (TWS) }\end{array}$ \\
\hline \multirow{7}{*}{$\begin{array}{c}\text { International } \\
\text { Journal-Un Paid } \\
\text { (with ISSN/ISBN) }\end{array}$} & \multirow{3}{*}{ H-Indexed } & 10 Above & 1 & \multirow{3}{*}{3} & 3 \\
\hline & & 10-May & 0.7 & & 2.1 \\
\hline & & $0-5$ & 0.4 & & 1.2 \\
\hline & \multirow{3}{*}{ Impact factor } & Above 3 & 1 & \multirow{3}{*}{2} & 2 \\
\hline & & $1.00-2.99$ & 0.7 & & 1.4 \\
\hline & & $0.01-0.99$ & 0.4 & & 0.8 \\
\hline & Other (Indexed) & $\begin{array}{c}\text { Peer } \\
\text { Reviewed/ } \\
\text { Refereed } \\
\end{array}$ & 0.5 & 1.5 & 0.75 \\
\hline \multirow{7}{*}{$\begin{array}{c}\text { International } \\
\text { Journal-Paid (JCR } \\
\text { Indexed) }\end{array}$} & \multirow{3}{*}{ H-Indexed } & 10 Above & 1 & \multirow{3}{*}{2} & 2 \\
\hline & & 10-May & 0.7 & & 1.4 \\
\hline & & $0-5$ & 0.4 & & 0.8 \\
\hline & \multirow{3}{*}{ Impact factor } & Above 3 & 1 & \multirow{3}{*}{1.75} & 1.75 \\
\hline & & $1.00-2.99$ & 0.7 & & 1.225 \\
\hline & & $0.01-0.99$ & 0.4 & & 0.7 \\
\hline & Other(Indexed) & $\begin{array}{c}\text { Peer } \\
\text { Reviewed/ } \\
\text { Refereed }\end{array}$ & 0.5 & 1.5 & 0.75 \\
\hline \multirow{7}{*}{$\begin{array}{l}\text { National Journals- } \\
\text { Unpaid }\end{array}$} & \multirow{3}{*}{ H-Indexed } & 10 Above & 1 & \multirow{3}{*}{1.5} & 1.5 \\
\hline & & 10-May & 0.7 & & 1.05 \\
\hline & & $0-5$ & 0.4 & & 0.6 \\
\hline & \multirow{4}{*}{ Impact factor } & Above 3 & 1 & \multirow{3}{*}{1.2} & 1.2 \\
\hline & & $1.00-2.99$ & 0.7 & & 0.84 \\
\hline & & $0.01-0.99$ & 0.4 & & 0.48 \\
\hline & & $\begin{array}{c}\text { Peer } \\
\text { Reviewed/ } \\
\text { Refereed }\end{array}$ & 0.5 & 0.8 & 0.4 \\
\hline \multirow{7}{*}{$\begin{array}{c}\text { National Journals- } \\
\text { Paid }\end{array}$} & \multirow{3}{*}{ H-Indexed } & 10 Above & 1 & \multirow{3}{*}{1} & 1 \\
\hline & & 10-May & 0.7 & & 0.7 \\
\hline & & $0-5$ & 0.4 & & 0.4 \\
\hline & \multirow{4}{*}{ Impact factor } & Above 3 & 1 & \multirow{3}{*}{0.8} & 0.8 \\
\hline & & $1.00-2.99$ & 0.7 & & 0.56 \\
\hline & & $0.01-0.99$ & 0.4 & & 0.32 \\
\hline & & $\begin{array}{c}\text { Peer } \\
\text { Reviewed/ } \\
\text { Refereed }\end{array}$ & 0.5 & 0.6 & 0.3 \\
\hline \multirow{2}{*}{$\begin{array}{l}\text { International } \\
\text { Conference } \\
\text { Proceedings } \\
\text { (Indexed) }\end{array}$} & With ISBN/ISSN & NA & 1 & 0.5 & 0.5 \\
\hline & $\begin{array}{l}\text { Without } \\
\text { ISBN/ISSN }\end{array}$ & NA & 0.8 & & 0.4 \\
\hline \multirow{2}{*}{$\begin{array}{l}\text { National } \\
\text { Conference } \\
\text { Proceedings } \\
\text { (Indexed) }\end{array}$} & With ISBN/ISSN & NA & 1 & 0.5 & 0.5 \\
\hline & $\begin{array}{l}\text { Without } \\
\text { ISBN/ISSN }\end{array}$ & NA & 0.8 & & 0.4 \\
\hline $\begin{array}{l}\text { Workshops/ } \\
\text { Symposiums }\end{array}$ & $\begin{array}{l}\text { With Funding by } \\
\text { other agencies }\end{array}$ & NA & 1 & 1 & 1 \\
\hline
\end{tabular}




\begin{tabular}{|c|l|c|c|c|c|}
\hline Organized & Without funding & NA & 0.5 & & 0.5 \\
\hline \multirow{2}{*}{$\begin{array}{c}\text { FDP/Workshops/ } \\
\text { Symposiums } \\
\text { Participated }\end{array}$} & International Level & NA & 1 & 0.5 & 0.5 \\
\cline { 2 - 6 } & National Level & NA & 0.6 & & 0.3 \\
\cline { 2 - 6 } & Others & NA & 0.4 & & 0.2 \\
\hline
\end{tabular}

Research and development is an integral part of innovation, the study considers that it is very essential for institutions and their staff to upgrade themselves and/or to upkeep the knowledge. Hence, it's considered to be very important for technical education. At this juncture, the author(s) supposed that there are multiple corners of research \& development criterion like, publications, participation in conferences, Workshops, Symposiums and FDP etc.

$$
\left(\sum \mathrm{RDS} \cdot \mathrm{W}_{\mathrm{RDS}}=\mathrm{TWS} \cdot \mathrm{W}_{\mathrm{RDS}}\right.
$$

Where TWS $=$ Total weighted score $=\left(\mathrm{W}_{\mathrm{pci}}\right) .\left(\mathrm{M}_{\mathrm{pci}}\right)$;

$\mathrm{W}_{\mathrm{pci}}=$ Wight of a paper category index; $\mathrm{M}_{\mathrm{pci}}=$ Maximum marks of a paper in given category

\subsection{Assessment of Other Activities Score}

The FINAL criterion of GHMPBI is Performance Appraisal for Other Activities Score (OAS) done by an employee. The following are the main features of this criterion:

i. OAS of GHMPB mainly considers three core areas of the Institute like, Faculty discipline in-terms of Punctuality, Faculty participation in Student counseling and Feedback of an employee from respective department HOD and Principal.

ii. This study also presumed that there are three additional qualities of faculty influences institutional growth. They are faculty discipline which includes punctuality, passion, innovation, integrity, patience etc.

iii. This study also assumed that the role faculty plays a vital role in motivating or encouraging students through proper counseling. Hence, this also given importance for student counseling.

iv. The strong PBI policy should respect Hierarchy and the feedback from peers.

From the view point of the above, the author allotted a thirty percentage of total score for this criterion. The Maximum score of this criterion is 3 Marks which includes:

$\begin{array}{lll}\text { Faculty Discipline } & - & 1 \text { Mark } \\ \text { Student Counseling } & - & 1 \text { Mark } \\ \text { HOD and Principal feedback } & - & 1 \text { Mark }\end{array}$

\section{Conclusion}

Incentives are instant rewards and they create immediate effect on performance. PBI policy always encourages employee competition rather that collaboration among employees. It delivers competitive pay for competitive levels of performance and also encourages employees to constantly develop new skills. With this motivation the author developed a geometric hybrid model for performance appraisal which is highly suitable for technical institutions. Hence, it creates competition among professors in terms of their results, research output correspondingly which uplifts the institute goals. Mainly the GHMPBI Policy considers all the core areas of a technical institutional objectives like, Academic Result (AR), Academic Feedback (AF), Research \& Development (RD) and other contributions (OC) of an employee for his/her improvement as well as institutional growth. This study experimented with few practical examples and analyzed with the given result. The developed policy considers all the parameters like student's results \& feedback, faculty research output and other contributions. This study may helpful in 
practical implementation in assessment of faculty appraisal and increments. At the outset it can be conclude that the review has been finished with sentiment happiness and loaded with fulfillment deserting the above proposal that it won't not be comprehensive but rather these would meet the changing desires of the personnel in specialized establishments in the field of technical institutions.

\section{Scope for Further Research}

In spite of the ample reviews and with appropriate research strategy and the utilization of full scale level essential information, the aftereffects of the present review can be put to further research. The review likewise made an endeavor of relative examination of execution evaluation which completed every one of the sides of examination components like, individual subject outcome, understudy criticism, staff research output and different commitments and so on. Other than those, other potential territories for research like the utilization of numerical condition on the elements of GHMPBI approach can offer valuable bits of knowledge for enhancing the viability of the operational elements of administration quality in specialized establishments, for which the present review examine work has provided a strong foundation to extend this review into programming model. This scientific model may tedious, Hence it would prescribe a modern programming model to deliver impartial outcomes with more precise and speed.

\section{Authors' Note and Declaration of Conflicting Interests}

Any mistakes remain the sole duty of the authors. The perspectives communicated in this article don't really mirror those of supporting organizations. The author(s) proclaimed no potential irreconcilable situations as for the exploration, initiation, or potentially distribution of this article. Be that as it may, all credits, translations, deficiencies or blunders are our sole responsibility.

\section{Acknowledgments}

The authors appreciate helpful comments and suggestions from management of VIGNAN'S institute of information technology and at the annual meetings of governing body. This work was supported by VIGNAN management. We would like to thank all the reviewers for their helpful comments and suggestions on earlier research. We are also thankful to our beloved chairman Dr. L. Rathaiah who encouraging in our research and also express my gratitude and heartfelt thanks to our beloved friend and colleague Professor Debnath Bhattacharyya who gave us a remarkable support to develop this article.

\section{References}

[1] C. Bueno and T. Sass, "Panel Paper: The Effects of Differential Pay on Teacher Recruitment, Retention and Quality", westat, (https://appam.confex.com/appam/2016/webprogram/Paper16396.html), (2016) November, pp. 1.

[2] R. Chamberlin, T. Wragg, G. Haynes and C. Wragg, "Performance-related pay and the teaching profession: a review of the literature", Research Papers in Education, vol. 17, no. 1, (2002), pp. 31-49.

[3] L. Darling-Hammond, "Doing What Matters Most: Investing in Quality Teaching. New York: National Commission on Teaching \& America's Future, (1997).

[4] L. Goe, "The link between teacher quality and student outcomes: A research synthesis", Washington, DC: National Comprehensive Center for Teacher Quality, (2008).

[5] D. Goldhaber, "The mystery of good teaching", Education Next, vol. 2, no. 1, (2002), pp. 50-55.

[6] E. A. Hanushek, J. F. Kain and S. G. Rivkin, "Why public schools lose teachers", Journal of Human Resources, vol. 39, no. 2, (2004), pp. 326-354.

[7] T. Hoerr, “A case for merit pay", Phi Delta Kappan, vol. 80, no. 4, (1998), pp. 326-27.

[8] C. K. Jackson, "Recruiting, retaining, and creating quality teachers", Nordic Economic Policy Review, vol. 3 , no. 1, (2012), pp. 1-52. 
[9] S. M. Johnson and J. P. Papay, "Redesigning teacher pay: A system for the next generation of educators", In S.P. Corcoran \& J. Roy (Eds.), EPI Series on Alternative Teacher Compensation Systems. Washington, DC: Economic Policy Institute, (2009).

[10] H. Lank Ford, S. Loeb and J. Wyckoff, "Teacher sorting and the plight of urban schools: A descriptive analysis", Educational Evaluation and Policy Analysis, vol. 24, no. 1, (2002), pp. 37-62.

[11] G. Liang, "Performance-related pay for teachers: An updated review. Journal of Postdoctoral Research", vol. 1, no. 1, (2013), pp. 99-117.

[12] M. G. Springer and L. L. Taylor, "Designing Incentives for Public School Teachers: Evidence from a Texas Incentive Pay Program”, Matthew G. Springer1 and Lori L. Taylor, Journal of education finance, winter, (2016), pp. 344.

[13] A. Mohrman, S. Mohrman and A. Odden, "Aligning Teacher Compensation with Systemic School Reform: Skill-Based Pay and Group-Based Performance Awards", Educational Evaluation and Policy Analysis, vol. 18, no. 1, (1996), pp. 51-71.

[14] A. Odden and C. Kelley, "Paying Teachers For What They Know And Do: New And Smarter Compensation Strategies To Improve Schools", Corwin Press, 2002, 2nd Edition, California.

[15] A. Odden, "Defining Merit", Education Matters, vol. 1, no. 1, (2001), pp. 16-24.

[16] M. J. Podgursky and M. G. Springer, "Teacher performance pay: A review", Journal of Policy Analysis and Management, vol. 26, no. 4, (2007), pp. 909-949.

[17] R. Richardson, "Performance Related Pay in Schools: An Assessment of the Green Papers - A report prepared for the National Union of Teachers", The London School of Economics and Political Science, (1999), pp. 1.

[18] J. Rockoff, "The impact of individual teachers on student achievement: Evidence from paneldata, American Economic Review, vol. 94, (2004), pp. 247-252.

[19] R. Balch and M. G. Springer, "Performance pay, test scores, and student learning objectives, Economics of Education Review, vol. 44, (2015), pp. 1.

[20] S. A. Imberman, "How effective are financial incentives for teachers?", IZA World of Labor, vol. 158, (2015), pp-1.

[21] L. Solomon and M. Podgursky, "The Pros and Cons of Performance-Based Compensation, Milken Family Foundation, Pascadena, (2001). 
International Journal of Advanced Science and Technology Vol.102 (2017) 